\title{
SOME SOCIAL AND ETHNIC VARIATIONS IN THE PHYSIQUE OF SOUTH AFRICAN NURSERY SCHOOL CHILDREN
}

\author{
BY \\ H. T. PHILLIPS \\ From the Institute of Family and Community Health, Union Health Department, Durban
}

(RECEIVED FOR PUBLICATION FEBruary 21, 1953)

Physical growth in children is a basic physiological process. Although growth is easily measured it is relatively infrequently used in the assessment of the well-being of the individual child. Stuart (1943) and Washburn (1950) have effectively put the case for studying growth of children and using bodily measurements as a routine in the clinical examination of children. It is therefore important to collect and analyse the basic data with which a child can be compared in the consulting room.

However, the limitations of the use of such standards must also be remembered. In a malnourished community the mean scores will be below optimal scores and attainment of the average or above average scores would give no automatic cause for satisfaction. Care must also be taken not to use the attained size of a child as the only index of its nutritional state. Very serious nutritional upsets, e.g. pellagra or scurvy, may occur in well covered children, and the development of oedema will of course give the weight of the child an entirely different meaning. Thus the physique of the child must be regarded as only a part of the clinical examination and must be taken in conjunction with the state of the individual tissues before assessing nutrition. In other words both quality and quantity of the tissues are important.

The rate of growth is considered more valuable than the attained size at a given age because 'growth is a form of motion' (Tanner, 1952) but such standards are more difficult to come by and have so far not been widely used. Serial measurements of a child are of greater value than single measurements because a big child may lose a considerable amount of weight and still be above the average for his age.

In these days of respect for mathematical exactitude it is important too to remember that there is a range of 'normal'. The use of the standard deviation with the mean will give the distribution of the scores in the particular group around that mean, provided the distribution is normal. Thus the mean -1 S.D. will include $68 \%$ and the mean 2 S.D. will include $95 \%$ of the group.

Another important use for somatometric standards is as an ancillary for the assessment of a community's health. Standards have been found to change temporally and have increased in countries such as the U.S.A. (Meredith, 1941), while in wartime Europe the standards with some exceptions dropped (Keys, Brožek, Henschel, Mickelsen and Taylor, 1950). Body size varies too with social and economic status, but ethnic influences have been difficult to separate from environmental factors (Meredith, 1941).

In South Africa little attention has been devoted to the study of the growth of children, and in the nursery school age group (2 to 6 years) only two published studies could be found (Woodrow and Robertson, 1950; Robertson, 1952). The present study has been undertaken with the object of remedying this deficiency and of stimulating the interest of paediatricians, nursery school workers and others interested in child welfare.

The data used in this study have been extracted from the records of 11 South African nursery schools and were divided into three groups:

1. White Upper-Income Group. These were children of professional, industrialist or managerial classes.

2. White Lower-Income Group. These were children from poorer suburbs whose parents were municipal and tramway workers, unskilled labourers, unemployed, etc.

3. Bantu Group. These were children living on a native sub-economic housing estate whose parents ranged from teachers and clerks to unskilled labourers. On the whole these children came from the better-off homes in an above-average urban native community. Nevertheless these children almost invariably showed signs of malnutrition when 
the skin and mucous membrane were examined. They were considerably superior in height and weight to a similar group of Bantu pre-school children near Pretoria reported by Robertson (1952).

The children were all weighed and measured at the nursery schools by members of their respective staffs in the mornings. In two of the schools (upper-income group nursery school and the Bantu nursery school) the children were weighed in the nude. In the remaining schools the children wore underclothes or light indoor clothes only. In all schools the scales were tested with a periodicity ranging from monthly to twice yearly.

Heights were measured with the child standing erect barefoot against a wall in nine of the 11 schools. In the two remaining schools (one upper-income group and one lower-income group) the child stood erect on the platform of a scale which was fitted with a vertical measuring rod and a horizontal arm which rested on the head.

Although there was no close uniformity in the methods used in the different schools it was apparent that serious attempts were made to make the measurements as accurate as the method used allowed.

The sources of the figures analysed are shown in Table 1. Thus there were 392 boys and 409 girls who

TABLE 1

DATA CONCERNING THE FIGURES USED FOR ANALYSIS

\begin{tabular}{|c|c|c|c|c|c|c|}
\hline & \multicolumn{2}{|c|}{$\begin{array}{l}\text { Upper- } \\
\text { Income } \\
\text { Group }\end{array}$} & \multicolumn{2}{|c|}{$\begin{array}{l}\text { Lower- } \\
\text { Income } \\
\text { Group }\end{array}$} & \multicolumn{2}{|c|}{$\begin{array}{l}\text { Bantu } \\
\text { Group }\end{array}$} \\
\hline & Boys & Girls & Boys & Girls & Boys & Girls \\
\hline No. of children .. & 143 & 115 & 140 & 176 & 109 & 118 \\
\hline $\begin{array}{l}\text { No. of measurements of } \\
\text { weight }\end{array}$ & 578 & 543 & 1,070 & 1,101 & 663 & 762 \\
\hline $\begin{array}{c}\text { Average no. of weights } \\
\text { per child }\end{array}$ & $4 \cdot 04$ & $4 \cdot 72$ & $7 \cdot 64$ & $6 \cdot 26$ & $6 \cdot 08$ & $6 \cdot 46$ \\
\hline $\begin{array}{l}\text { No. of measurements of } \\
\text { height } . . \\
\end{array}$ & 526 & 513 & 1,070 & 1,097 & 495 & 601 \\
\hline $\begin{array}{c}\text { Average no. of heights } \\
\text { per child } \quad \ldots \quad \ldots\end{array}$ & $3 \cdot 68$ & $4 \cdot 46$ & $7 \cdot 64$ & $6 \cdot 23$ & $4 \cdot 54$ & $5 \cdot 09$ \\
\hline $\begin{array}{l}\text { Durban nursery schools } \\
\text { Period of Survey }\end{array}$ & $\left(1943^{1}\right.$ & 1947) & - & - & (1947- & $1951)$ \\
\hline $\begin{array}{l}\text { Johannesburg nursery } \\
\text { schools } \\
\text { Period of Survey }\end{array}$ & $\left(1946^{3}\right.$ & 1948) & $\left(1936^{5}\right.$ & 1946) & - & - \\
\hline $\begin{array}{l}\text { Capetown nursery } \\
\text { schools } \\
\text { Period of Survey }\end{array}$ & $\left(1946^{1}\right.$ & 1949) & - & - & - & - \\
\hline
\end{tabular}

were weighed 4,717 times and had their heights measured 4,302 times between the ages of $2 \frac{1}{4}$ and $6 \frac{1}{4}$ years of age. Not more than one measurement each for height and weight for each quarter year of each child's age were used in the analysis that follows.
Findings and Discussion

The findings for boys and girls in the three groups are shown in Tables 2 and 3.

Difference between the Sexes. Most authors giving heights and weights for pre-school children separate the sexes (Greenwood, 1913; Peatman and Higgons, 1938; Kincaid and Stuckey, 1938; Gore and Palmer, 1949; Simmons, 1944; Mitchell and Nelson, 1945; Robertson, 1952). A few have not done so (Sheldon, 1943; Woodrow and Robertson, 1950). In those cases where the sexes have been separated the boys have usually been taller and heavier than the girls over the period from 2 to 6 years with the tendency for the differences to lessen towards the end of the period. The study published by Robertson (1952) was exceptional. His heights and weights were those of Bantu pre-school children attending a crêche near Pretoria and on the whole his girls were taller and heavier than his boys.

Table 4 summarizes the sex differences found in the present study.

It can be seen that the upper-income group children roughly followed the pattern usually found and the boys were generally heavier and taller than the girls. The lower-income group boys were generally heavier than girls of the corresponding ages, but after the age of $3 \frac{1}{2}$ years the girls were nearly always superior in height. However, the superiorities in height of the girls were small in most cases and the average superiority in height amounted to only 0.03 inches over the 17 ages used for comparison.

In the Bantu group the boys were generally inferior in weight, but slightly superior in height so that the girls were more stockily built. None of the individual comparisons gave a difference which was statistically significant.

As far as we are aware little Bantu girls in this particular community receive no treatment which would account for their unusual weight superiority over the boys. It is, however, interesting to note that Kark (1952), in discussing the stature and weight of Bantu school children in the Pholela Native Reserve, concludes that 'when compared with other boys and girls (Pretoria European, British and American of various racial and ethnic groups) it would seem that Pholela boys are somewhat more retarded in stature and weight than are the Pholela girls'. In this group of school children the boys showed a higher incidence of clinical signs of malnutrition than the girls.

Obviously further investigation of bigger samples is required to confirm or refute the results of this study. The child-rearing techniques used in Bantu families should also be investigated in case there are factors which produce heavier girls than boys. 
Comparison of the Groups. The upper-income group boys were found to be heavier and taller than lower-income group boys of the corresponding ages. The differences were 3 to $5 \mathrm{lb}$. in weight and 2 to $2 \frac{1}{4}$ in. in height. These differences were all significant in each age group from $2 \frac{3}{4}$ to $5 \frac{1}{2}$ years.
The upper-income group girls were consistently heavier and taller than the lower income group girls of the corresponding ages. The differences were 2 to $4 \frac{1}{2} \mathrm{lb}$. and $1 \frac{1}{4}$ to $2 \frac{1}{2}$ in. These differences were all significant in each age group from $2 \frac{1}{2}$ to $5 \frac{1}{4}$ years.

The lower-income group boys' weights were higher

TABLE 2

WEIGHTS OF SOUTH AFRICAN NURSERY SCHOOL CHILDREN

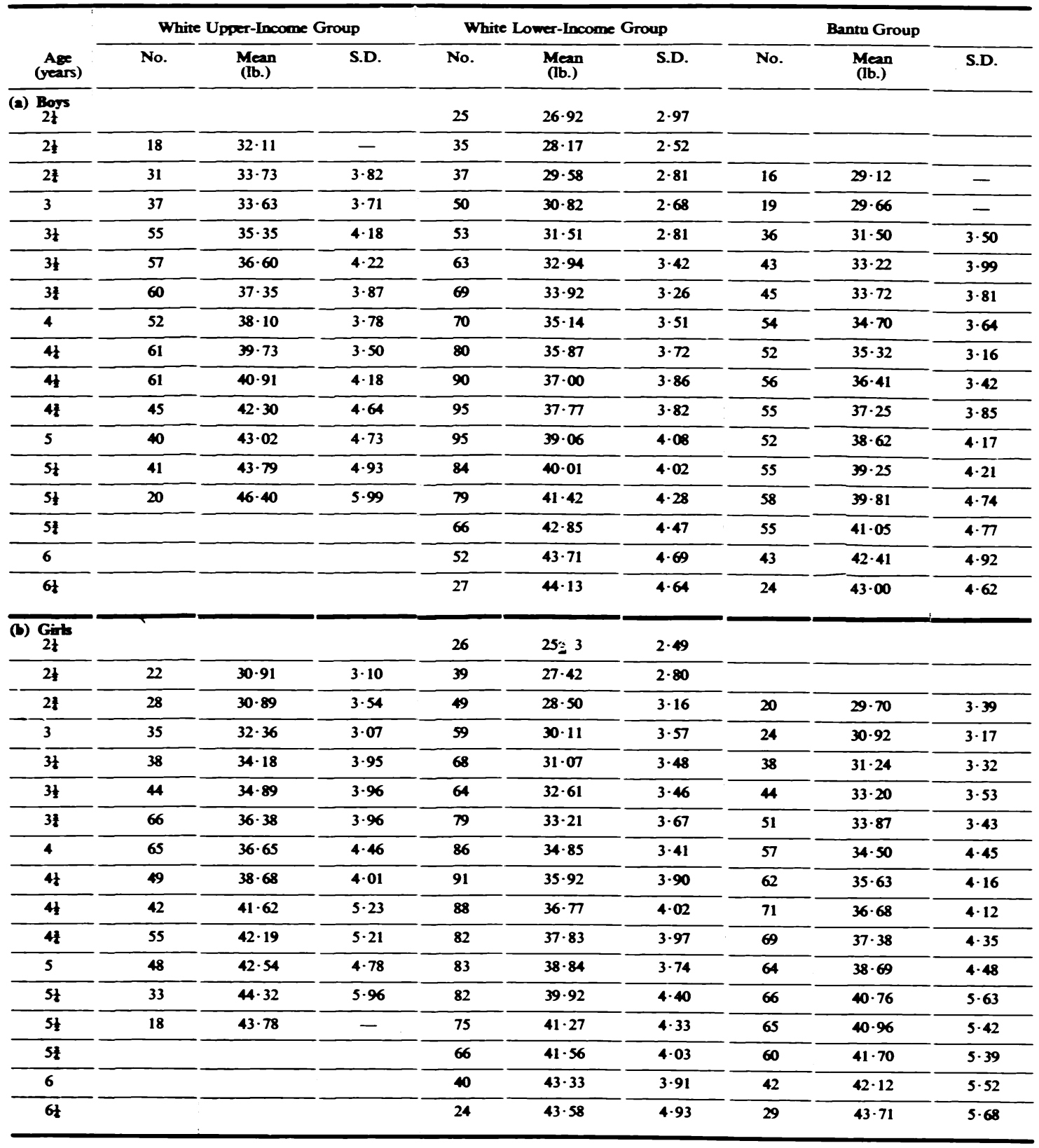


(with one exception) than those of the Bantu boys, significant at $44,4 \frac{1}{2}, 4 \frac{3}{4}, 5 \frac{1}{2}, 5 \frac{3}{4}$ and 6 years. the differences being $1.8 \mathrm{lb}$. or less. Only in the $5 \frac{3}{4}$ age group was the difference $(1 \cdot 8 \mathrm{lb}$.) significant. The lower-income group boys' heights were greater than those of Bantu boys by 0.26 to 1.35 in. Between 31 and 6 years of age the differences were

The lower income group girls were heavier than the Bantu girls in seven out of 15 age groups. The difference in the various age groups ranged from $1 \cdot 2$ lb. to $-1 \cdot 2 \mathrm{lb}$. and none of the differences was significant.

TABLE 3

HEIGHTS OF SOUTH AFRKCAN NURSERY SCHOOL CHILDREN

\begin{tabular}{|c|c|c|c|c|c|c|c|c|c|}
\hline \multirow[b]{2}{*}{$\begin{array}{c}\text { Age } \\
\text { (years) }\end{array}$} & \multicolumn{3}{|c|}{ White Upper-Income Group } & \multicolumn{3}{|c|}{ White Lower-Income Group } & \multicolumn{3}{|c|}{ Bantu Group } \\
\hline & No. & $\begin{array}{l}\text { Mean } \\
\text { (lb.) }\end{array}$ & S.D. & No. & $\begin{array}{l}\text { Mean } \\
\text { (in) }\end{array}$ & S.D. & No. & $\begin{array}{l}\text { Mean } \\
\text { (in) }\end{array}$ & S.D. \\
\hline $\begin{array}{l}\text { (a) Boys } \\
2 t\end{array}$ & & & & 25 & $33 \cdot 37$ & $1 \cdot 44$ & & & \\
\hline $2 \frac{1}{2}$ & 15 & $36 \cdot 58$ & - & 35 & $34 \cdot 30$ & $1 \cdot 38$ & & & \\
\hline 21 & 28 & $37 \cdot 39$ & $2 \cdot 10$ & 37 & $35 \cdot 30$ & $1 \cdot 24$ & & & \\
\hline 3 & 34 & $38 \cdot 13$ & $1 \cdot 30$ & 50 & $36 \cdot 14$ & $1 \cdot 14$ & 16 & $34 \cdot 94$ & - \\
\hline $3 t$ & 47 & $39 \cdot 07$ & 1.82 & 53 & $36 \cdot 89$ & $1 \cdot 31$ & 27 & $36 \cdot 36$ & $2 \cdot 26$ \\
\hline $3 \frac{1}{2}$ & 55 & $39 \cdot 64$ & $1 \cdot 46$ & 63 & $37 \cdot 42$ & $1 \cdot 38$ & 34 & $37 \cdot 16$ & $1 \cdot 97$ \\
\hline 31 & 53 & $40 \cdot 41$ & $1 \cdot 48$ & 69 & $38 \cdot 07$ & $1 \cdot 47$ & 32 & $37 \cdot 47$ & $1 \cdot 69$ \\
\hline 4 & 45 & $41 \cdot 01$ & $1 \cdot 31$ & 70 & $38 \cdot 87$ & 1.51 & 41 & $38 \cdot 33$ & $2 \cdot 06$ \\
\hline 44 & 57 & $41 \cdot 70$ & $1 \cdot 27$ & 80 & $39 \cdot 45$ & 1.58 & 43 & $38 \cdot 73$ & $1 \cdot 48$ \\
\hline 41 & 59 & $42 \cdot 44$ & $1 \cdot 36$ & 90 & $40 \cdot 13$ & $1 \cdot 72$ & 41 & $39 \cdot 13$ & $1 \cdot 68$ \\
\hline 41 & 37 & $42 \cdot 82$ & 1.82 & 95 & 40.82 & $1 \cdot 76$ & 44 & $40 \cdot 11$ & 1.45 \\
\hline 5 & 41 & $43 \cdot 59$ & $1 \cdot 74$ & 95 & $41 \cdot 54$ & $1 \cdot 80$ & 40 & $40 \cdot 80$ & $2 \cdot 07$ \\
\hline $5 t$ & 39 & $44 \cdot 22$ & 1.63 & 84 & $42 \cdot 11$ & 1.79 & 42 & $41 \cdot 50$ & 2.02 \\
\hline 51 & 16 & 44.99 & - & 79 & 42.92 & 1.68 & 44 & 41.99 & 1.92 \\
\hline 51 & & & & 66 & $43 \cdot 78$ & 1.66 & 41 & $42 \cdot 64$ & 1.64 \\
\hline 6 & & & & 52 & $44 \cdot 34$ & $1 \cdot 70$ & 33 & 42.99 & $1 \cdot 79$ \\
\hline $6 t$ & & & & 27 & $44 \cdot 49$ & $1 \cdot 58$ & 17 & $43 \cdot 60$ & - \\
\hline $\begin{array}{l}\text { (b) Girts } \\
2 \downarrow\end{array}$ & & & & 25 & 33.09 & 1.56 & & & \\
\hline 21 & 22 & $36 \cdot 34$ & 1.03 & 38 & 33.91 & $1 \cdot 27$ & & & \\
\hline 21 & 26 & $37 \cdot 46$ & $1 \cdot 37$ & 48 & $34 \cdot 76$ & $1 \cdot 37$ & 17 & $34 \cdot 25$ & - \\
\hline 3 & 34 & $37 \cdot 85$ & $1 \cdot 31$ & 58 & 36.02 & 1.59 & 13 & $34 \cdot 98$ & - \\
\hline 31 & 35 & $38 \cdot 89$ & $1 \cdot 78$ & 68 & $36 \cdot 76$ & $1 \cdot 76$ & 32 & $35 \cdot 10$ & $1 \cdot 60$ \\
\hline 31 & 40 & $39 \cdot 30$ & 1.53 & 64 & $37 \cdot 42$ & 1.53 & 30 & $36 \cdot 57$ & 1.89 \\
\hline $3 z$ & 64 & 40.08 & 1.48 & 84 & $38 \cdot 19$ & $1 \cdot 58$ & 43 & 37.06 & $1 \cdot 76$ \\
\hline 4 & 60 & 40.73 & 1.52 & 85 & 39.05 & 1.66 & 39 & $38 \cdot 10$ & $2 \cdot 10$ \\
\hline 4 & 48 & $41 \cdot 56$ & $1 \cdot 26$ & 90 & 39.72 & $1 \cdot 78$ & 47 & $38 \cdot 72$ & $1 \cdot 71$ \\
\hline 41 & 42 & 42.62 & 1.49 & 87 & $40 \cdot 22$ & 1.69 & 51 & $39 \cdot 58$ & 1.67 \\
\hline 41 & 47 & 42.91 & 1.46 & 82 & $41 \cdot 12$ & $1 \cdot 60$ & 56 & 40.03 & 1.73 \\
\hline 5 & 47 & 43.46 & $1 \cdot 54$ & 81 & $41 \cdot 80$ & $1 \cdot 74$ & 53 & $40 \cdot 58$ & $1 \cdot 75$ \\
\hline $5 t$ & 33 & 43.92 & $1 \cdot 7$ & 84 & 42.65 & 1.66 & 50 & $41 \cdot 92$ & 1.49 \\
\hline 51 & 15 & $44 \cdot 48$ & - & 74 & $43 \cdot 13$ & 1.87 & 99 & $42 \cdot 17$ & 1.98 \\
\hline $5 !$ & & & & 66 & 43.67 & $1 \cdot 84$ & 48 & $42 \cdot 50$ & 1.74 \\
\hline 6 & & & & 39 & $44 \cdot 42$ & $2 \cdot 37$ & 36 & $42 \cdot 79$ & 2.04 \\
\hline $6 t$ & & & & 24 & $44 \cdot 58$ & 1.44 & 27 & 43.86 & 1.91 \\
\hline
\end{tabular}


TABUE 4

SEX DIFFERENCES IN WEIGHT AND HEIGHT OF NURSERY SCHOOL CHILDREN*

\begin{tabular}{|c|c|c|c|c|c|c|}
\hline \multirow[t]{2}{*}{ Ages } & \multicolumn{2}{|c|}{$\begin{array}{l}\text { Upper-Income } \\
\text { Group }\end{array}$} & \multicolumn{2}{|c|}{$\begin{array}{l}\text { Lower-Income } \\
\text { Gioup }\end{array}$} & \multicolumn{2}{|c|}{ Bantu Group } \\
\hline & $\begin{array}{l}\text { Weights } \\
\text { (lb.) }\end{array}$ & $\begin{array}{l}\text { Heights } \\
\text { (in) }\end{array}$ & $\begin{array}{l}\text { Weights } \\
\text { (lb.) }\end{array}$ & $\begin{array}{l}\text { Heights } \\
\text { (in) }\end{array}$ & $\begin{array}{l}\text { Weights } \\
\text { (lb.) }\end{array}$ & $\begin{array}{l}\text { Heights } \\
\text { (in.) }\end{array}$ \\
\hline 21 & & & $-1 \cdot 19$ & $+\cdot 28$ & & \\
\hline 21 & $-1 \cdot 20$ & -.21 & -0.75 & $-\cdot 39$ & & \\
\hline 21 & $-2 \cdot 84$ & -.07 & -1.08 & +.54 & -.58 & \\
\hline 3 & $-1 \cdot 27$ & $-\cdot 28$ & -0.71 & $-\cdot 12$ & $-1 \cdot 26$ & -.04 \\
\hline $3 t$ & $+1 \cdot 17$ & $T \cdot 18$ & -0.44 & $-\cdot 13$ & $-\cdot 26$ & $-1 \cdot 26$ \\
\hline $3 \pm$ & $-1 \cdot 71$ & $-\cdot 34$ & $-0 \cdot 33$ & 0 & +.02 & +.59 \\
\hline 31 & -0.97 & -.33 & -0.71 & $-\cdot 12$ & $-\cdot 15$ & $\div \cdot 41$ \\
\hline 4 & $+1 \cdot 45$ & $-\cdot 28$ & $-0 \cdot 29$ & $-\cdot 18$ & +.20 & $+\cdot 23$ \\
\hline 41 & -1.05 & $-\cdot 14$ & -0.05 & -.27 & $-\cdot 31$ & +.01 \\
\hline 41 & -0.71 & $-\cdot 18$ & $-0 \cdot 23$ & -.09 & $-\cdot 27$ & -.45 \\
\hline 41 & $+0 \cdot 11$ & -.09 & $-\cdot 16$ & $-\cdot 30$ & $-\cdot 13$ & +.08 \\
\hline 5 & -0.48 & $-\cdot 13$ & -.22 & $-\cdot 26$ & -.07 & $\perp \cdot 22$ \\
\hline 54 & -0.56 & $-\cdot 30$ & -.09 & -.54 & $-1 \cdot 51$ & -.42 \\
\hline 51 & -2.62 & -.51 & $-\cdot 15$ & $-\cdot 21$ & $-1 \cdot 15$ & $-\cdot 18$ \\
\hline 54 & & & $+1 \cdot 29$ & $-\cdot 11$ & -.65 & $+\cdot 14$ \\
\hline 6 & & & $+\cdot 38$ & -.08 & $+\cdot 29$ & $T \cdot 20$ \\
\hline 64 & & & $+\cdot 52$ & -.09 & $-\cdot 71$ & -.26 \\
\hline Average & $-1 \cdot 04$ & $-\cdot 18$ & -.48 & -.03 & -.40 & $+\cdot 13$ \\
\hline
\end{tabular}

The lower-income group girls were taller than the Bantu girls by 0.72 to 1.66 in. in the age groups $3 \frac{1}{4}$ to $6 \frac{1}{4}$ years. All the differences were significant except at 6 and $6 \frac{1}{4}$ years.

It follows that the upper-income group children were heavier and taller than the Bantu children of the corresponding sex and age groups. Wherever a comparison could be made the differences were found to be significant.

On the whole it can be stated that: (1) Upperincome group boys and girls were three-quarters of a year in advance of lower-income group boys and girls respectively both in weight and in height. (2) Lower-income group boys were equal to or up to a quarter of a year in advance of Bantu boys in weight and about a quarter of a year in advance in height. (3) Lower-income group girls were about equal to Bantu girls in weight and about a quarter of a year in advance in height. It seems therefore that the economic group to which a child belongs is more powerful in determining the size of the nursery school age child than the ethnic group.

Comparison with Other Stadies. It is interesting to compare the heights and weights of our two samples of white children with those obtained in other countries. Tables $5 \mathrm{a}$ and $5 \mathrm{~b}$ show the figures obtained in the present series compared with studies. in America, Australia and England.

Study of these figures reveals that the South African upper-income group children are equal or slightly superior to two superior groups of American children with regard to weight and height. On the other hand, the South African lower-income group children were lighter and shorter than children of similar economic groups in London and Melbourne.

The heights and weights given by Woodrow and Robertson (1950) for Cape Town children cannot easily be brought into this comparison because the sexes have been combined in their series. In general, however, their weights and heights for white (European) children fall between those of the upperincome and the lower-income groups. Their coloured* (non-European) children are 2 to $7 \mathrm{lb}$. lighter than the Bantu groups while their heights are approximately the same so that their children must be more slender in build.

It must be emphasized that comparisons between different studies must be accepted with caution because of the absence of uniformity of methods of measurement.

\section{Summary}

The uses and limitations of somatometric tables for height and weight are discussed as measures of individual and of group health.

The heights and weights of 392 boys and 409 girls attending 11 South African nursery schools have been divided into three groups, viz., white upperincome group, white lower-income group and Bantu group.

Analysis of these measurements reveals the following main findings: (a) The upper-income group boys are taller and heavier than upper-income group girls of the same ages. (b) The lower-income group boys are heavier but slightly shorter on the whole than lower-income group girls. (c) The Bantu boys are lighter but taller on the whole than Bantu girls. (None of these differences between the sexes in each class was significant.) (d) The upper-income group boys were significantly heavier and taller than the lower income group and the Bantu boys. $(e)$ The upper-income group girls were significantly heavier and taller than the lower-income group and the Bantu girls. $(f)$ The lower-income group boys were usually heavier and taller than the Bantu boys, the weight differences being significant at one age only, and the height differences significant at most ages after $4 \frac{1}{4}$ years. $(g)$ The lower-income group girls were approximately the same weight as the Bantu girls,

\footnotetext{
* 'Coloured' consists of a mixed group derived from White, Malay, Bantu, Hottentot and other ethnic groups.
} 
TABLE 5

COMPARISON OF PRESENT SERIES WITH RESULTS IN OTHER COUNTRIES*

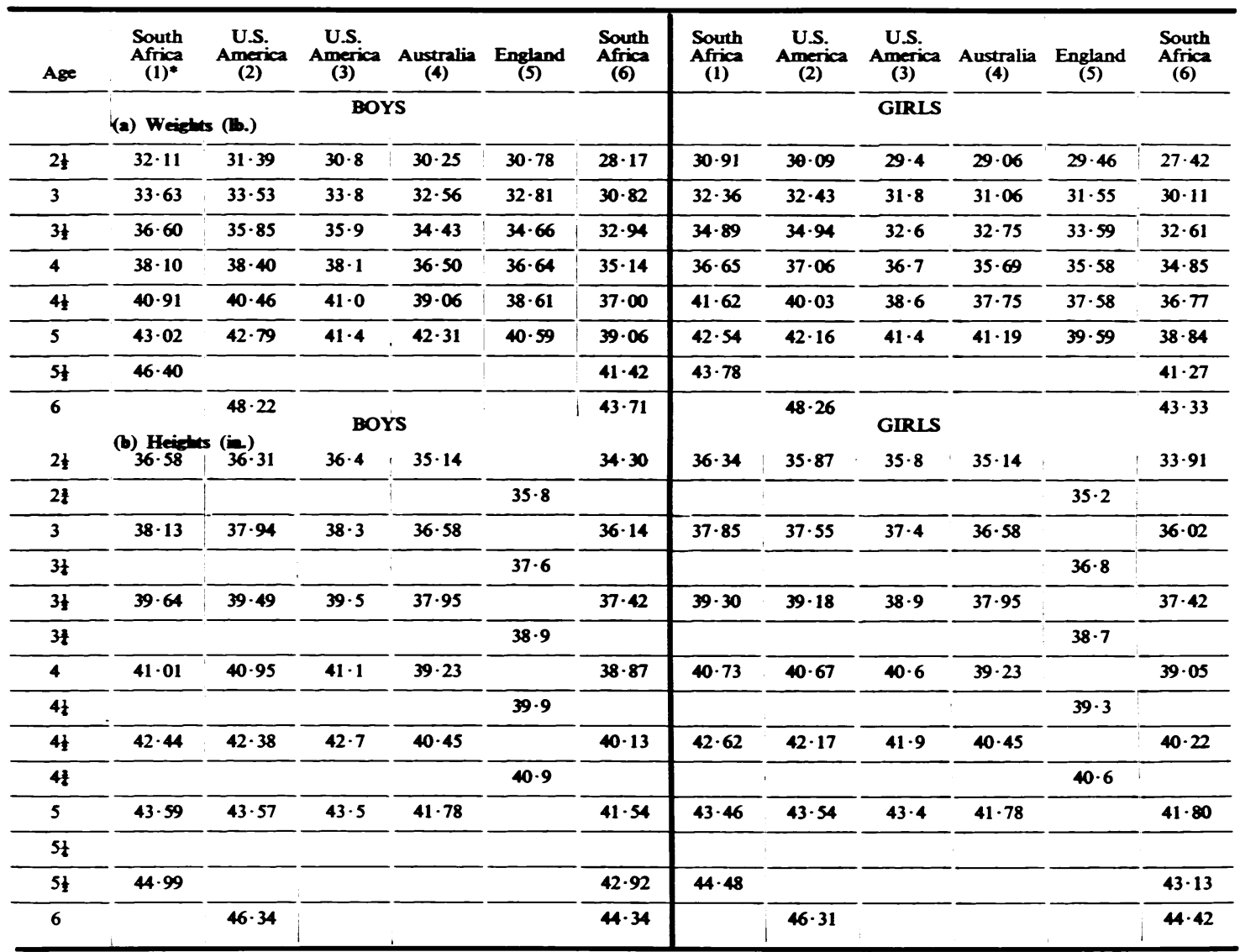

- (1) Present series, upper-income group white children from three South African cities 1943-1949. (2) Simmons (1944) children of above average parents economically and educationally in Cleveland, U.S.A., 1932-1942. (3) Peatman and Higgons (1938) middle and well-to-do classes children having optimal home añd paediatric care in New York (no period stated). (4) Kincaid and Stuckey (1938) children 'with no defects' from poorer classes in Melbourne (no period stated). (5) Gore and Palmer (1949) children attending L.C.C. clinies in London, 1947. (6) Present series, lower-income group white children from Johannesburg (1936-1946).

but the former were taller (significantly so at most ages) than the latter.

The heights and weights of the South African children are compared with those recently obtained in other countries. The upper-income group children are superior or equal to the best overseas standards. The lower-income group and Bantu are inferior to the worst of these standards.

Thanks are due to the Secretary for Health for permission to publish this paper, to Dr. S. L. Kark and Mrs. E. Bradshaw of the Institute of Family and Community Health for their advice and assistance, to Mrs. B. Sterner and Mr. V. Pollak and his colleagues for their cooperation in collecting data, and to the supervisors of the various nursery schools for permission to use their records.
RerEenences

Gore, A. T. and Palmer, W. T. (1949). Lancet, 1, 385.

Greenwood, A. (1913). The Health and Physique of School Children.

Kark. S. L. (1952). The Nutritional State of Pholela Schoolchildren. (In the library of the Institute of Family and Community Health, Merebank, Durban.)

Keys, A., Brožet. J., Henschel, A., Mickelsen, O. and Taylor, H. L. (1950). The Biology of Human Starnation, vol. II 991-1001. University of Minnesota Press. Minneapolis.

Kincaid H. E and Stuckey, M. (1938). Med. J. Aust. 1, 575.

Meredith, H. V. (1941). Amer. J. Dis. Child., 62 909.

Meredith, H. V. (1941). Amer. J. Dis. Child, 62 909. of Pediatrics. 4th ed. Philadelphia.

Peatman, J. G. and Higgons, R. A. (1938). Amer. J. Dis. Child., 55 , 1233.

Robertson. A. S. (1952). Trans. roy. Soc. trop. Med. Hyg, 46, 560.

Sheldon, W. (1943). Diseases of Infancy and Childhood. 4th edit. Churchill, London.

Simmons, K. (1944). The Brush Foundation Study of Child Growth and Development II. Physical Growth and Development. Monogr. Soc. Res. Child Developm., 9, No. 1 (Serial No. 37)

Stuart, H. C. (1943). Amer. J. Dis. Child., 65, 320.

Tanner, J. M. (1952). Archives of Disease in Childhood, 27, 10.

Washburn, A. H. (1950). Pediatrics, $5,765$.

Woodrow, E. P. and Robertson, I. (1950). S. Afr. med. J., 24, 761. 